\title{
A Comparative Study of International and Chinese Public Health Emergency Management from the Perspective of Mapping Knowledge Domains
}

Juan Li

School of Public Health, Weifang Medical University, Weifang 261053, People's Republic of China Yuhang Zhu

School of Public Health, Weifang Medical University, Weifang 261053, People's Republic of China; Center for Psychosocial Medicine, University Medical Center Hamburg-Eppendorf, Hamburg 20246, Germany

\section{Jianing Feng}

School of Public Health, Weifang Medical University, Weifang 261053, People's Republic of China

\section{Weijing Meng}

School of Life Science and Technology, Weifang Medical University, Weifang 261053, People's Republic of China

\section{Kseniia Begma}

School of Foreign Languages, Weifang Medical University, Weifang 261053, People's Republic of China

\section{Gaopei Zhu}

School of Public Health, Weifang Medical University, Weifang 261053, People's Republic of China

\section{Xiaoxuan Wang}

School of Public Health, Weifang Medical University, Weifang 261053, People's Republic of China

\section{Di Wu}

Department of Teaching Quality Monitoring and Evaluation, Weifang Medical University, Weifang 261053, People's Republic of China

\section{Fuyan Shi ( $\square$ shifuyan@126.com )}

School of Public Health, Weifang Medical University, Weifang 261053, People's Republic of China

\section{Suzhen Wang ( $\nabla$ wangsz@wfmc.edu.cn )}

School of Public Health, Weifang Medical University, Weifang 261053, People's Republic of China

\section{Research Article}

Keywords: Public health, Emergency management, Knowledge domains

Posted Date: August 24th, 2020

DOl: https://doi.org/10.21203/rs.3.rs-63718/v1 
License: (c) (i) This work is licensed under a Creative Commons Attribution 4.0 International License. Read Full License 


\section{Abstract}

Background: At the end of 2019, the outbreak of the coronavirus disease 2019 (COVID-19) had severely damaging people's life. China's public health emergency management system had played an essential role in the handling and response of it, which had been appreciated by the World Health Organization and some countries. Hence it is necessary to make an overall analysis of the development of China's health emergency management system. It can provide a reference for scholars to understand the current situation and look for new research points.

Methods: We collected 2247 international from the Web of Science database, 959 Chinese articles from China National Knowledge Infrastructure database. Bibliometric and mapping knowledge domains analysis methods were used in this study for temporal distribution analysis, cooperation network, co-word network analysis.

Results: The first international article in this field was published in 1991, while Chinese in 2005. Research institutions mainly come from universities and health institutions. Developed countries and European countries published more articles, while east of China published more. There are 52 burst words for international articles from 1999-2018, while 18 burst words for Chinese articles from 2003-2018. International top-ranked articles by citation appeared in 2005, 2007, 2009, 2014, 2015, 2016, while Chinese appeared in 2003, 2004, 2009, 2011.

Conclusions: There are differences in the regional or economic distribution of international and Chinese cooperation networks. International research often relates to hot issues, mainly focus on the emergency preparedness and monitoring for public health events, while China's focus on the public health emergency and their disposal. International begins the research with terrorism and bioterrorism, followed by disaster planning and emergency preparedness, epidemics and infectious diseases. China takes severe acute respiratory syndrome as the research background and legal system construction as the research starting point, followed by mechanism, structure, system, and learning from abroad of public health emergency management.

\section{Background}

Public health emergencies are increasing to recent years, which show a trend to cause considerable damages [ $\left.{ }^{1}\right]$. According to the Emergency Events Database (EM-DAT), the most widely used and influential disaster database in the world, the average number of deaths per major public health events was more than 10,000 [2]. Population growth, urban development, migration, and other issues brought about by globalization had sped up the incidence of public health events, such as epidemics $\left[{ }^{3},{ }^{4}\right]$. Public health events also had pushed the process of high gear giving top priority to changes in emergency operations. The outbreak of the coronavirus disease 2019 (COVID-19) in China spread rapidly to the whole world in a short time, which illustrated the need to build a resilient health emergency system that can withstand epidemics [5]. 
Public health emergency management (PHEM) is a relatively new field that draws on specific sets of knowledge, techniques, and organizing principles found in emergency management [ $\left.{ }^{6}\right]$. Specifically speaking, it includes the planning, organization, leadership, coordination, control, evaluation, prevention, preparation, response for the public health emergencies [ $\left.{ }^{7}\right]$. For COVID-19, China's PHEM system had been quickly taken measures as follows: Emergency Mobilization Measures Within Government, Block Down Cities and Communities, Nationwide Medical Mobilization, Provide Financial Support, and Preferential Policies to Medical Community and Pharmaceutical Industry, Category Comprehensive Publicity of Prevention and Treatment Knowledge $\left[{ }^{8}\right]$. These measures had effectively reduced the spread of the disease. Thus, current recommendations are mostly derived from the reported Chinese experience $\left[{ }^{9}\right]$. Given the weaknesses and deficiencies exposed by the COVID-19 outbreak, people have recognized the need to improve the national PHEM system $\left[{ }^{10},{ }^{11}\right]$.

A growing body of research had studied PHEM from different perspectives, mainly including the institutions, funds, technologies, laws. Public health emergency was a severe challenge to health institutions such as hospitals, the Center for Disease Prevention and Control (CDC), and governments [7, $\left.{ }^{12}\right]$. These challenges were characterized by sustainability, redundancy, and flexibility [ $\left.{ }^{13}\right]$. Fund and technology resources can merge the roles and responsibilities of public health preparedness and emergency management $\left[{ }^{14}\right]$. Once there were severe deficiencies in legal preparedness that can undermine effective responses to public health emergencies $\left[{ }^{15},{ }^{16}\right]$. Those were the essential factors of deal with public health emergencies. Also, many countries took corresponding measures to strengthen emergency management of public health. For example, the United States had established a PHEM operations center either independently in the health department or as a part of the overall command system in the government $\left[{ }^{17}\right]$. China established the PHEM system from the national level to the local level to be responsible for emergency preparedness and response in 2004 [17]. In March 2018, the Ministry of Emergency Management of the People's Republic of China was established, which was an integral part of the State Council. Thus, we can see that PHEM is still a hot topic for scholars and governments $\left[{ }^{18},{ }^{19}\right]$.

However, there are still some problems that need to be solved. To our best knowledge, little evidence could tell the differences that happened in international and Chinese PHEM. Moreover, what are the hotspots and trends of PHEM? What are the main research forces of PHEM? Therefore, it is necessary to sort out the characteristics of the development of PHEM, explore the hotspots of PHEM research. Also, compare the research on PHEM between international and Chinese. Based on this situation, we reviewed the articles on PHEM that published in nearly 30 years in international and Chinese journals. Then, we used the method of knowledge map to reveal the research strength, frontier, and development trends in this field. Study conclusions are helpful to draw people's attention to public health emergencies, provide a reference for scholars to understand the current situation and trends of PHEM, and for government departments to formulate guidance strategies.

\section{Methods}




\section{Data Sources}

Data were divided into two categories: International and Chinese data. According to relevant authoritative research $\left[{ }^{20}\right]$, the database of bibliometric methods should contain complete documents. A considerable amount of literature showed that Web of Science (WoS) was the largest comprehensive academic information resource, covering peer-reviewed journals with high impact factors [ $\left.{ }^{21}-24\right]$. According to this all, the international data used for our study were collected from the WoS Core Collection, including Science Citation Index Expanded (SCl-E), Science Citation Index Expanded (SSCl), and Arts \& Humanities Citation Index $(\mathrm{A} \& \mathrm{HCl})$ databases. Chinese data was downloaded from the China National Knowledge Infrastructure (CNKI), which had the largest Chinese journal full-text database, including the vast majority of Chinese journals relating to public health management. More importantly, it has become one of the critical basic data sources for bibliometrics research in China $\left.{ }^{25}\right]$.

\section{Data Retrieval}

Data obtained by inappropriate literature information retrieval strategy could not accurately reflect the content of the research $\left.{ }^{26}\right]$. Emergency management was a common term in China that focused on the occurrence, development, evolution of emergencies, and finding effective ways of responding to the emergency $\left[{ }^{27}\right]$. However, it was not certified for international. After consulting the experts from the Chinese CDC who once worked for the World Health Organization (WHO), we learned that the management was refined by preparedness, operation, response, and recovery for an international public health emergency. Also, this had been mentioned in articles $\left[5,{ }^{28}\right]$. Based on the above points, the international data retrieval strategies were set as: $((T S=$ public health) AND $(T S=$ preparedness OR TS= operation OR TS= response OR TS= recovery) AND TS= (emergency )) AND LANGUAGE: (English) AND DOCUMENT TYPES: (Article) Indexes = SCI-EXPANDED, SSCl, A\&HCl, Timespan $=1988-2018$. When retrieving Chinese data, we choose "public health" and "emergency management" as the theme-word, Timespan = "1988-2018". We ran the search query of WoS and CNKI on February 19, 2019. A total of 2759 articles from 1991 to 2018 were retained from WoS, while 999 articles from 2003 to 2018 were retained from CNKI.

After discussing with the team members, we further selected the articles based on inclusion and exclusion criteria to ensure that all of the data were closely aligned to the study targets. The inclusion criteria are as follows: (1) Occurrence, development, and evolution of PHEM; (2) Prevention, preparedness, response, operation and recovery of PHEM system; (3) Planning, organization, leadership, coordination, and control of public health emergency; (4) Practice and method of PHEM. Exclusion criteria as follows: (1) Health care, medical record management, disease treatment; (2) Guidelines on the action, proceedings paper or book chapter, interviews, summaries of conferences, and patent abstracts. Finally, 2247 international articles and 959 Chinese articles were accepted for the analysis after data filtering and removing duplication. The international articles were downloaded by the "Plain Text" format with a full record and cited references to classification and statistical analysis. The Chinese articles were downloaded by the "Refworks" format. Those download data contain the list of authors, the title of the 
publication, the abstract, keywords, and so on. With this, we had obtained the data for this study. Figure 1 shows the specific search steps.

\section{Data Analysis Tools}

We used CiteSpace 5.5.R2 and Microsoft Excel 2016 for the data analysis. CiteSpace was a free Javabased application found by Chaomei Chen to analyze the potential knowledge contained in the scientific literature. It had been widely adopted for scientometric analysis in various scientific fields $\left[{ }^{29}\right]$, and have achieved excellent results $\left[{ }^{30},{ }^{31}\right]$. The parameters of CiteSpace for this study were set as follows: time slicing (1991-2018, 2003-2018, respectively), years per slice (1), term source (all selection), node type (Author, institution, keyword, for Chinese and international data. Country for international data.), selection criteria (top 50), and visualization (cluster view-static, show merged network). The corresponding other settings were selected according to different study questions. Microsoft Excel 2016 was used for temporal distribution and polynomial prediction of the number of articles. It should be noted that the results of the CNKI database made by CiteSpace were presented in Chinese. In order to make it easier to read, we translated the Chinese result into English.

\section{Data Analysis Strategies}

This study involved using bibliometric and mapping knowledge domains analysis method. Bibliometric methods provided an approach to identify the development trends or future research orientations by the combining of different tools and methods to analyze the articles $\left[{ }^{32}, 33\right]$. It allowed researchers to generate information from historical data and indicators, such as keywords, authors, institutes, countries ${ }^{[34}$. We were mainly engaged in cooperation network analysis (including the network analysis of the authors, institutions, and countries), co-word network analysis (including keyword co-occurrence network and burst detection analysis) in the mapping knowledge domains analysis. First, we made a statistical analysis of the temporal distribution of relevant articles. Then, we made a polynomial prediction of the number of articles, fitted the trend line of international and Chinese study, and predicted it in the next three years. Cooperation network analysis was used to analyze the contribution to different authors, institutions, countries in one field. It was obvious that the more an author, a country, or an institution publish its research findings, the more contributions it will make [35]. Betweenness centrality is an index to measure the importance of nodes in the network. The purple circle represented documents with betweenness centrality not less than 0.1 , which meant the authors, institutions, or countries occupied an essential position in this field $\left[20,{ }^{36}\right]$. Co-word analysis was a content analysis technique that was effective against mapping co-occurrence relationships and the strength of the relationship between a pair of items existing in the same text, revealing the inner construction of a research field [24]. Analysis of keywords co-occurrence network was meaningful and valuable in exploring the hot topics in a specific knowledge domain $\left[{ }^{37}, 38\right]$. Besides, keywords burst detection analysis can clearly grasp the articles that receive particular attention to the related scientific communities in a certain period. Therefore, the frontiers founded by the burst detection analysis can provide researchers with up-to-date information [ ${ }^{39}$, 
${ }^{40}$ ]. The analysis of the highly cited articles in the field can reflect the development of the discipline in a period, study hot topics, and supplement the above results, to provide a reference for scientific researchers topic selection $\left[{ }^{41}\right]$.

\section{Results}

\section{Temporal Distribution Analysis}

Figure 2 showed us the first international article on PHEM was published in 1991. The number of articles fluctuated slowly in the next few years. After 2001, it began to increase rapidly. It was worth noting that the number of articles in 2014 is high, reaching 206. It declined in the next two years. Until 2017, the number of articles reached its peak, 219. The study on PHEM in China started in 2003 and declined slowly until 2005. During 2006-2013, there was a rapid development; many articles appeared in this period. The minimum number in 2006 also reached 41, the maximum was in 2013, reaching an astonishing 96 . Thus, the average number also peaked at 70.0. The number of articles declined after 2013, reaching 49 in 2018. In contrast, the study in China started late than in some countries, yet a large number of Chinese scholars participated in this study at the beginning.

After the descriptive analysis of the data, we conducted a polynomial prediction analysis of the number of articles and predicted it in the next three years. The trend of chronological distribution of articles related to PHEM in international data can be expressed as follows: $y=0.2790 x^{2}+0.7688 x-7.7708\left(R^{2}=\right.$ $0.9577)$, while Chinese data was: $y=-0.0345 x^{3}+1.5079 x^{2}-14.142 x+27.273\left(R^{2}=0.9251\right) . Y$ indicated the number of articles and $x$ indicated the years. $R^{2}>0.9$, indicating a good degree of fit. The chronological distribution of international articles showed a trend of the increasing year by year. In 2019-2021, the annual number of articles will exceed that of previous years. At the same time, the trend line of Chinese articles like a wave line, and the number of articles will continue to decrease to the next three years. Besides, as time goes on, the gap in the number of articles in Chinese and international will be gradually increasing.

\section{Cooperation Network Analysis}

\section{Co-Author}

Figure 3, the international co-author network, showed that there were many authors studied on PHEM, and some had collaborated. The top-ranked item by citation counts was Daniel J. Barnett (DANIEL J BARNETT in the figure) with a citation count of 20 (all the count did not show in the figure). Then was Elena Savoia (ELENA SAVOIA) and Lainie Rutkow (LAINIE RUTKOW); all their citation counts were 17. These were authors who paid great attention to this field and had published more articles. Most of these authors were from American universities, such as Johns Hopkins University, Harvard University. The topranked items by centrality were Frederick M. Brokle (FREDERICK M), Task Force for Pediatric Emergency 
Mass Critical Care (TASK FORCE PEDIAT EMERGENCY MASS C CA) and James G. Hodge (JAMES G), with the centrality of 0.06 (all the centrality did not show in the figure). However, all three items' centrality was less than 0.1. Figure 4, the top-ranked item for Chinese scholars by citation counts was Qunhong Wu with citation counts of 22. Then was Yanhua Hao (17), Feng Han (11), Ning Ning (10), Yadong Wang (10), Zheng Kang (8), Ying Liu (6), Jincheng Ma (6), Mingli Jiao (5), Libo Liang (5). Most of them were teachers at Harbin Medical University. The top-ranked items by centrality were Yanhua Hao, and Ning Ning, with the centrality of 0.02 . The third one was Qunhong Wu, with the centrality of 0.01 . Their nodes' centrality also less than 0.1 . In terms of the quantity and quality of articles, Qunhong Wu and Yanhua Hao were the leaders of PHEM in China. From the co-author network, we can see that many authors in internationally and China are collaborating on PHEM. (Additional file 1: Table S1, Table S2, and Figure S1).

\section{Co-Institution}

Just like a co-author, many institutions had studied on PHEM (figure 5 and figure 6). The top-ranked item by international citation counts was the Centers for Disease Control and Prevention (Ctr Dis Control \& Prevent.), with citation counts of 255 , which means that the institution publishes the largest number of articles in this field. The second one was Johns Hopkins University (Johns Hopkins Univ.), with citation counts of 92, and it meant that Johns Hopkins University had the largest number of articles published among the universities in this field. Then was Harvard University (Harvard Univ.), Columbia University (Columbia Univ.), and so on. The above analysis showed that CDC and universities were the leading institutions to study on international PHEM. The centrality ranked item was CDC (0.50). Then was Johns Hopkins University (0.21), Harvard University (0.16), University of Washington (Univ Washington., 0.13), University of Toronto (Univ Toronto., 0.10), University of Pittsburgh (Univ Pittsburgh, 0.10 ) and Boston University (Boston Univ., 0.10). All these nodes' centrality was no less than 0.1 with the purple circle, which meant that they were the institutions with higher publication quality and the leading institutions in this field. The top-ranked item by citation counts of the Chinese database was the School of Health Management, Harbin Medical University, with citation counts of 20. Then was Shanghai Publishing and Printing College (9), National Health and Family Planning Commission of the People's Republic of China (7), School of Health Administration and Education, Capital Medical University (6), and so on. The topranked item by centrality was the School of Health Management, Harbin Medical University, with a centrality of 0.04 . The second one was the China National Health Development Research Center, with the centrality of 0.03 . Then, we can see the School of Health Management, Harbin Medical University is a leader in the field of research in China. In comparison, $\mathrm{CDC}$ had the largest publication volume and influence in the international, while universities dominated the field of research instead of health institutions in China. (Additional file 1: Table S3, Table S4, and Figure S2).

\section{Co-Country}

Table 1 summarized the top 10 countries in the count and centrality of international PHEM research. We can see that the development of PHEM researches differs from countries, and it mainly centralized in the 
USA, Canada, England, Australia, P. R. China, Switzerland, Italy, Sweden, Japan, Netherlands. According to the income levels from the World Bank $\left[{ }^{42}\right]$, these countries were all high-income countries except China. Geographically, half of them centralized in Europe. Among these countries, the USA was the most productive country, far ahead of the rest in this field, and its centrality was the largest. This showed that in the field of PHEM, the USA carries out the most study, and their study was more advanced. Although China ranks fifth in the number, its centrality was only 0.03 . Therefore, these results indicated that Chinese scholars could publish some internationally recognized articles in the field, which had an advantage in quantity; but, they need to improve the articles' quality. It was worth noting that although the number of Switzerland (44) and Sweden (34) articles was much lower than that of the USA, the articles' centrality of these two countries was more than 0.10 , which showed that the quality of the articles was still high.

\begin{tabular}{|c|c|c|c|}
\hline Count & Country & Centrality & Country \\
\hline 1557 & USA & 0.67 & USA \\
\hline 138 & Canada & 0.32 & England \\
\hline 131 & England & 0.16 & Switzerland \\
\hline 114 & Australia & 0.16 & Sweden \\
\hline 95 & P. R. China & 0.11 & Canada \\
\hline 44 & Switzerland & 0.08 & Germany \\
\hline 34 & Italy & 0.06 & Australia \\
\hline 34 & Sweden & 0.06 & India \\
\hline 30 & Japan & 0.04 & Netherlands \\
\hline 27 & Netherlands & 0.03 & P. R. China \\
\hline
\end{tabular}

Abbreviation: P. R. China = People's Republic of China

\section{Co-word Network Analysis}

\section{Keywords Co-occurrence Network Analysis}

Generally speaking, keywords represent the research hotspots, which means topics of wide concern for researchers in this field. From figure 7 we can saw, top 10 keywords ranked by citation counts for the international database was public health (297), preparedness (215), emergency preparedness (191), 
disaster (187), health (142), emergency (133), care (128), United States (121), bioterrorism (102), and impact (96). The top ten centrality was emergency department (0.22), prevalence (0.18), surveillance $(0.17)$, knowledge $(0.15)$, public health preparedness $(0.15)$, children $(0.14)$, management $(0.14)$, trauma (0.13), simulation (0.13), policy ( 0.11$)$. All their centrality was more than 0.10 , which meant they had more influence than other keywords. Figure 8 showed top 10 keywords of Chinese PHEM research was public health emergencies (394), emergency management (154), health emergency (116), public health (101), emergencies (84), emergency response ability (78), public health events (58), emergency mechanism (33), emergency disposal (28), public emergencies (27). Nodes whose centrality over 0.1 was health emergency (0.45), public health (0.32), public health emergencies $(0.30)$, emergency management $(0.26)$, emergencies (0.23), public health events (0.13), and emergency response ability (0.12). Comparing the distribution of keywords in the international and Chinese, we can see that the international study mainly focuses on the emergency preparedness and monitoring for public health events, while the Chinese research mainly focuses on the analysis and disposal for it. (Additional file 1: Table S5, Table S6, and Figure S3).

\section{Burst Detection Analysis}

Figure 9 and figure 10 illustrated the keywords with the strongest citation burst for international and Chinese databases. The international keywords detected 52 burst words, while the Chinese data detected 18 burst words. Research frontier of international PHEM included anthrax, public health, weapon, bioterrorism, accident, trauma, terrorism, emergency response, and so on. Among these words, bioterrorism (28.7902) was the strongest burst keyword, which was during the period between 2002 and 2009. Then was Ebola $(15.6855,2015-2018)$, disaster planning $(10.2745,2014-2016)$, terrorism $(9.9846,2004-2008)$. All these showed us a greater attention to this study topic and better exemplify the study front in this period. From the perspective of the time development sequence, international research on PHEM begins with terrorism and bioterrorism. After that, disaster planning and emergency preparedness have become a new research frontier (2004-2014). In recent years (2015-2018), epidemics and infectious diseases have become the focus of study. Research frontier of Chinese PHEM included public health emergencies, United States of America, North America, emergency disposal, united states, sudden events, public health, emergency, emergency response, public emergencies, disease prevention and control agency, evaluate, emergency drill, risk assessment, assessment, health emergency management, health emergency response ability, Delphi method. During 2003-2008, Chinese research on PHEM was in its infancy. The main research frontiers were public health emergencies and America. It was mainly at the stage of the formation of the Chinese theory of this field. By learning from the experience of the United States in dealing with health emergencies, scholars began the study of PHEM in China. Then, Chinese scholars began to study the links involved in the disposal of public health emergencies, such as response, organization, evaluation, exercise, and evaluation of PHEM. After 2016, health emergency management, health emergency response ability, and the Delphi method had become the new research front. In contrast with international and Chinese research on PHEM, it can be found that international research often relates to hot issues, while China focuses on the management procedure (Additional file 1: Figure S4). 
In order to further explain the above research hotspots, the top 8 cited articles were shown in table 2 and table 3. The top 8 ranked articles by citation for international database appeared in the year of 2005 , $2007,2009,2014,2015,2016$. The article Elevated blood lead levels in children associated with the flint drinking water crisis: a spatial analysis of risk and public health response was the most cited (372) international article [43]. Then was The 2006 California Heat Wave: Impacts on Hospitalizations and Emergency department visits [ $\left.{ }^{44}\right]$. In terms of the time distribution, the research on international bioterrorism started first $\left[{ }^{45}\right]$, then was recommendations for health emergency response teams and health incident management $\left[{ }^{46},{ }^{47}\right]$. In recent years, the causes and disposal of public health events were the hotspots of international attention $\left[43,{ }^{48}-\right]$. This was basically consistent with the analysis results of the above research keywords. Chinese top 8 cited articles of PHEM, appeared in the year of 2003, 2004, 2009,2011 . Table 3 showed us that the most frequently cited Chinese article was Emergency logistics $\left[{ }^{51}\right]$ written by Zhongwen Ou, Huiyun Wang, Dali Jiang et al. frequency reached an astonishing number, 473. Secondly, Kaibin Zhong's article Review and prospect: construction of emergency management system in China [ $\left.{ }^{52}\right]$. The three articles: Legislative situation and characteristics of China's emergency law [ $\left.{ }^{53}\right]$, Legal construction of public emergency response in China: legal construction task proposed by SARS crisis management practice $\left.{ }^{54}\right]$, The realistic subject of administrative rule of law in public emergency management ${ }^{55]}$ mainly researched the legal construction of PHEM in China. They all published in 2003, proving that China mainly carried out the research on the legal construction of PHEM during that time. In other words, PHEM in China starts with legal system construction. In 2004, Chinese scholars began to establish a knowledge domain for health emergency response and disposal. With the extensive research, Chinese scholars began to research on international PHEM in 2011. 
Table 2 Top 8 cited articles of international database

\begin{tabular}{|c|c|c|c|c|}
\hline Count & Author & Title & Journal & Year \\
\hline \multirow[t]{2}{*}{372} & \multirow{2}{*}{$\begin{array}{l}\text { Mona Hanna- } \\
\text { Attisha, Jenny } \\
\text { LaChance, Richard } \\
\text { Casey Sadler, et al. }\end{array}$} & $\begin{array}{l}\text { Elevated blood lead levels in } \\
\text { children associated }\end{array}$ & \multirow[t]{2}{*}{$\begin{array}{l}\text { American Journal of } \\
\text { Public Health }\end{array}$} & \multirow[t]{2}{*}{2016} \\
\hline & & $\begin{array}{l}\text { with the flint drinking water } \\
\text { crisis: a spatial analysis of risk } \\
\text { and public health response }\end{array}$ & & \\
\hline 366 & $\begin{array}{l}\text { Kim Knowlton, } \\
\text { Miriam Rotkin- } \\
\text { Ellman, Galatea } \\
\text { King, et al. }\end{array}$ & $\begin{array}{l}\text { The } 2006 \text { California Heat Wave: } \\
\text { Impacts on Hospitalizations and } \\
\text { Emergency department visits }\end{array}$ & $\begin{array}{l}\text { Environmental Health } \\
\text { Perspectives }\end{array}$ & 2009 \\
\hline 365 & $\begin{array}{l}\text { Karin Stettler, } \\
\text { Martina Beltramello, } \\
\text { Diego A. Espinosa, } \\
\text { et al. }\end{array}$ & $\begin{array}{l}\text { Specificity, cross-reactivity, and } \\
\text { function of antibodies elicited } \\
\text { by Zika virus infection }\end{array}$ & Science & 2016 \\
\hline \multirow[t]{2}{*}{316} & Nathalie Embriaco & \multirow{2}{*}{$\begin{array}{l}\text { High level of burnout in } \\
\text { intensivists - Prevalence and } \\
\text { associated factors }\end{array}$} & \multirow{2}{*}{$\begin{array}{l}\text { American Journal of } \\
\text { Respiratory and Critical } \\
\text { Care Medicine }\end{array}$} & \multirow[t]{2}{*}{2007} \\
\hline & $\begin{array}{l}\text {,Elie Azoulay, Karine } \\
\text { Barrau, et al. }\end{array}$ & & & \\
\hline \multirow[t]{2}{*}{305} & \multirow[t]{2}{*}{$\begin{array}{l}\text { Salim S. Abdool } \\
\text { Karim, Gavin J. } \\
\text { Churchyard, } \\
\text { Quarraisha Abdool } \\
\text { Karim, et al. }\end{array}$} & $\begin{array}{l}\text { Health in South Africa } 3 \text { HIV } \\
\text { infection and tuberculosis in } \\
\text { South Africa: an urgent need to } \\
\text { escalate the public health }\end{array}$ & \multirow[t]{2}{*}{ Lancet } & \multirow[t]{2}{*}{2009} \\
\hline & & response & & \\
\hline 286 & $\begin{array}{l}\text { Daniel P. Aldrich, } \\
\text { Michelle A. Meyer. }\end{array}$ & $\begin{array}{l}\text { Social Capital and Community } \\
\text { Resilience }\end{array}$ & $\begin{array}{l}\text { American Behavioral } \\
\text { Scientist }\end{array}$ & 2014 \\
\hline 238 & $\begin{array}{l}\text { Lawrence M. Wein, } \\
\text { Yifan Liu. }\end{array}$ & $\begin{array}{l}\text { Analyzing a bioterror attack on } \\
\text { the food supply: The case of } \\
\text { botulinum toxin in milk }\end{array}$ & $\begin{array}{l}\text { Proceedings of the } \\
\text { National Academy of } \\
\text { Sciences of the United } \\
\text { States of America }\end{array}$ & 2005 \\
\hline 226 & $\begin{array}{l}\text { Philip J. Peters, } \\
\text { Pamela Pontones, } \\
\text { Karen W. Hoover }\end{array}$ & $\begin{array}{l}\text { HIV Infection Linked to Injection } \\
\text { Use of Oxymorphone in Indiana, } \\
2014-2015\end{array}$ & $\begin{array}{l}\text { The New England } \\
\text { Journal Of Medicine }\end{array}$ & 2016 \\
\hline & , et al. & & & \\
\hline
\end{tabular}


Table 3 Top 8 cited articles of Chinese database

\begin{tabular}{|c|c|c|c|c|}
\hline Count & Author & Title & Journal & Year \\
\hline 473 & $\begin{array}{l}\text { Zhongwen Ou, } \\
\text { Huiyun Wang, } \\
\text { Dali Jiang et } \\
\text { al. }\end{array}$ & Emergency logistics & $\begin{array}{l}\text { Journal of } \\
\text { Chongqing } \\
\text { University (Natural } \\
\text { Science Edition) }\end{array}$ & 2004 \\
\hline 177 & Kaibin Zhong. & $\begin{array}{l}\text { Review and prospect: construction of } \\
\text { emergency management system in China }\end{array}$ & $\begin{array}{l}\text { CASS Journal of } \\
\text { Political Science }\end{array}$ & 2009 \\
\hline 122 & Jihong Mo. & $\begin{array}{l}\text { Legislative situation and characteristics of } \\
\text { China's emergency law }\end{array}$ & Legal Forum & 2003 \\
\hline 102 & Yuchuan Mo. & $\begin{array}{l}\text { Legal construction of public emergency } \\
\text { response in China: legal construction task } \\
\text { proposed by SARS crisis management } \\
\text { practice }\end{array}$ & $\begin{array}{l}\text { Journal of Renmin } \\
\text { University of China }\end{array}$ & 2003 \\
\hline 94 & Yuchuan Mo. & $\begin{array}{l}\text { The realistic subject of administrative rule } \\
\text { of law in public emergency management }\end{array}$ & Jurists Review & 2003 \\
\hline 77 & $\begin{array}{l}\text { Yifeng Yang, } \\
\text { Chenfang } \\
\text { Fan, } \\
\text { Guangwen } \\
\text { Cao. }\end{array}$ & $\begin{array}{l}\text { Emergency management in immediate } \\
\text { response to emergent public health event } \\
\text { in China }\end{array}$ & $\begin{array}{l}\text { Academic Journal } \\
\text { of Second Military } \\
\text { Medical University }\end{array}$ & 2004 \\
\hline 69 & $\begin{array}{l}\text { Lexuan Luo, } \\
\text { Zhanchun } \\
\text { Feng, Jian } \\
\text { Zhang. }\end{array}$ & $\begin{array}{l}\text { Research on the hospital function of } \\
\text { response to public health emergency }\end{array}$ & $\begin{array}{l}\text { Chinese Hospital } \\
\text { Management }\end{array}$ & 2004 \\
\hline 65 & $\begin{array}{l}\text { Liping Fan, } \\
\text { Qinghua } \\
\text { Zhao. }\end{array}$ & $\begin{array}{l}\text { The status quo of emergency management } \\
\text { system for sudden public health events in } \\
\text { America and Japan and its enlightenment }\end{array}$ & $\begin{array}{l}\text { Chinese Nursing } \\
\text { Research }\end{array}$ & 2011 \\
\hline
\end{tabular}

\section{Discussion}

International research on PHEM is earlier than the Chinese one, and it has been growing over time. This means that international scholars pay more and more attention to PHEM. In 1991, the first article on PHEM was written by Richard L. Siegel, named Code 9: a systematic approach for responding to medical emergencies occurring in and around a hospital $\left[{ }^{56}\right]$. It mentioned the need for an organized system to respond to such emergencies involving patients, visitors, local community residents, and hospital employees, both inside the hospital and on the grounds surrounding the building. They recommend the establishment of a systematic emergency response system in all health care institutions. Since then, academia has begun to pay attention to emergency management of public health incidents. The number of international articles is increasing gradually, reaching the maximum in 2017 , and it is expected to continue to grow in the next three years. The development of PHEM in China shows a fluctuating pattern. The occurrence of public health emergencies in the ten years, from 2006 to 2016, showed a general trend 
of rising first and then slowly declining. It is likely related to the number of significant events that occur in each year $\left[{ }^{57}\right]$. The severe acute respiratory syndrome (SARS) epidemic in 2003 resulted in significant increases in both the amount of research and articles on emergency management [7]. The number of articles reached a small climax in 2008. Events such as the Wenchuan earthquake, the southern snow disaster happened in that year. The maximum was in 2013, human infection with H7N9, Ya'an earthquake, death from hepatitis $B$ vaccine happened in that year. Moreover, it was ten years after the SARS outbreak; some authors compared the development of PHEM in China for ten years. The first Chinese article on PHEM was written by Tiewu Jia, named Capacity-building for public health emergency response to disasters (2003) [ $\left.{ }^{58}\right]$. This article was published during the epidemic of SARS. In 2003, China did not established a network and echelon PHEM system. The author combined the development of emergency management, reform of health and epidemic prevention institutions, discussed the capacity building of public health emergency response. It is helpful for the social function orientation of the disease control center and the improvement of the disease prevention ability. Although the number of Chinese articles decreased in the following years, it remained above 48. In a word, the above analysis shows that PHEM is still a hot topic.

From the perspective of cooperative networks, we find that there is more cooperation among Chinese authors, yet less cooperation among the authors from different institutions. The cooperation between different research institutions is believed to be highly effective in facilitating high-level and fruitful research, which can also help develop the research field into a more established area [ $\left.{ }^{59}\right]$. Therefore, Chinese scholars should strengthen cooperation between different institutions. The research institutions on PHEM mainly come from universities and health institutions, while Chinese has regional differences. Reasons include that the western region had the poor fiscal capacity, a limited personnel size, and an inadequate stockpile in terms of working budget, timely reserves, and prompt delivery $\left[{ }^{60}\right]$. As a leader in international PHEM, CDC had begun to help other entities strengthen their capacity, recognition, and technical expertise to strengthen their PHEM capacity [ $\left.{ }^{61}\right]$. Also, some other health institutions, such as the WHO, had promoted the development in this field. In 2005, the $58^{\text {th }}$ World Health Assembly (WHA) adopted the revised International Health Regulations, which instructed the WHO member states to collaboratively confront public health emergencies of global attention $\left[5,17,{ }^{62}\right]$. Universities have undertaken the scientific task of PHEM, and they have conducted in-depth research on it in China. Chinese CDC has carried out more disease prevention and control services; its scientific research ability is slightly weak. The country network analysis shows obvious differences in regional and economic development levels for PHEM. Those countries with more developed health emergency management systems are the most high-income ones. Geographically, most of these countries are concentrated in Europe, where numbers of publications and citations are also significantly higher [60]. The United States, the United Kingdom, Japan, and other countries have built and improved their PHEM constantly, which has become a comprehensive management network.

The co-word analysis on the international research of PHEM is more complex, extensive, and multidimensional. They reflect some of the major ideas of this research. Based on them, scholars mainly 
focus on emergency preparedness and monitoring for public health events. From the perspective of Chinese PHEM development, it has gone through a process from theory to preparation, disposal, response, evaluation, organization, and discussion. That is to say, the main contents of China's health emergency management include the prevention and preparation of health emergencies, as well as the key links of disposal, evaluation and management, system construction, personnel training, and so on. In a word, the development of the whole discipline is systematic and clear. The keywords that with the strongest citation burst of international research on PHEM started with terrorism and bioterrorism $\left[{ }^{63}\right]$, then disaster planning and emergency preparedness. In recent years, epidemics and infectious diseases have become the new research frontier. From the perspective of the whole development context, international research on PHEM has been related to current affairs hotspots, such as the terrorism may originate from the 9.11 incident, and the epidemics may be related to the epidemic of infectious diseases caused by viruses and bacteria such as Ebola virus. While the study of PHEM in China is a process from theory formation to practice discussion, involving many links of management. During 2003-2008, Chinese scholars focus on the health emergency response and disposal. After that, Chinese scholars began to learn more about foreign PHEM models. Some new methods are gradually applied to Chinese PHEM in recent years.

The top-ranked articles by citation for international knowledge domain of PHEM, appeared in the year of $2005,2007,2009,2014,2015,2016$. In 2005, Lawrence M. Wein [45] developed a mathematical model of a cows-to-consumers supply chain to reduce the bioterrorism event. Once again, it shows that the international emergency management research is based on terrorism and bioterrorism. In 2007, Nathalie Embriaco focused on the working condition of emergency management personnel [46]. Kim Knowlton [44] and Salim S. Abdool Karim [47], mentioned the emergency department. The above three articles are all about the factors involved in health emergency management. The remaining articles analyze the specific events involving the mechanism, response, and recovery [43, 48-50]. From the above analysis, it can be seen that terrorism, emergency response and health incident management, disposal of public health events are the hotspots of international attention. Legislative situation and characteristics of China's emergency law [53], Legal construction of public emergency response in China: legal construction task proposed by SARS crisis management practice [54], and The realistic subject of administrative rule of law in public emergency management [55] were published in 2003. All three articles discussed the problems existing in the construction of the administrative legal system under the background of SARS. After that, three articles were published in 2004, mainly studied the mechanism and structure of PHEM in China. It was proposed to establish the emergency response mechanism for PHEM and establish emergency structure construction as soon as possible. In 2009, Kaibin Zhong wrote the article Review and prospect: construction of emergency management system in China [52]. He elaborated on the core contents of Chinese PHEM construction, including emergency plan, emergency structure, emergency mechanism, and legal system. China's PHEM integrates emergency systems, emergency mechanisms and legal systems in an all-round way, which is characterized by comprehensiveness, institutionalization, openness, and guarantee. In 2011, The status quo of emergency management system for sudden public health events in America and Japan and its enlightenment $\left[{ }^{64}\right]$ was published, showed us China is

Page $15 / 29$ 
learning the theory and experience of PHEM in some advanced countries. From the above analysis, it can be seen that the legal system, mechanism and structure, system, and learning from abroad are the theoretical guidance for the Chinese PHEM in the past 30 years.

Admittedly, there are some limitations. Firstly, conclusions drawn from this study were based on only two large literature retrieval libraries. Other databases such as Embase, Springer Link were not studied. Not being able to search all the literature in this field may lead to the retrieval results incomplete. Secondly, CiteSpace has some shortcomings in processing the results of the Chinese database; it cannot translate the result from Chinese into English directly. Thirdly, one year or more time lag is between our papersubmitted and published. The database articles may change during this time. Fourthly, although we conducted a comparison between Chinese and international databases, like many similar studies. It should be acknowledged that the two databases had different acceptance ratio, and this difference in data sources might lead to bias in the study results. Besides, we categorized those English articles focus on China into an international database, did not analyze them alone. Although only a small part of it, that may have some deficiencies. This may constitute the object of future studies, namely analyze the differences between English papers focusing on China vs. Chinese papers.

\section{Conclusions}

In summary, we selected two large documents of retrieval library to define the PHEM domain, detected the research status and trends of it from 1991 to 2018. According to the analyses, conclusions are as follows. In the next three years, the number of international PHEM articles will continue to increase, while the Chinese will decline. Chinese scholars have less cooperation among different organizations. There are differences in regional or economic distribution between international and Chinese cooperation networks. China focuses on the east regionally, while developed countries and European countries are more international. International research often relates to hot issues, mainly focus on the emergency preparedness and monitoring for public health events, while China's focuses on the public health emergency and their disposal. The research of PHEM in international begins with terrorism and bioterrorism, followed by disaster planning and emergency preparedness and emerging infectious diseases. China takes SARS as the research background and legal system construction as the research starting point, followed by mechanism and structure, system, and learning from abroad.

\section{Abbreviations}

EM-DAT: Emergency Events Database; COVID-19: coronavirus disease 2019; PHEM: Public Health Emergency Management; CDC: Center for Disease Prevention and Control; WoS: Web of Science; SCI-E: Science Citation Index Expanded; SSCl: Social Sciences Citation Index; A\&HCl: Arts \& Humanities Citation Index; CNKI: China National Knowledge Infrastructure; WHO: World Health Organization; HIV: Human Immunodeficiency Virus; AIDS: Acquired Immune Deficiency Syndrome; SARS: severe acute respiratory syndrome; WHA: World Health Assembly 


\section{Declarations}

\section{Acknowledgments}

All authors thank the three experts in China for their valuable advice on literature search and selection. Members of the expert group are Zhen Xu (Health Emergency Center, Chinese Center for Disease Control and Prevention, Beijing); Ting Zhang (Health Emergency Center, Chinese Center for Disease Control and Prevention, Beijing; School of Public Health, Weifang Medical University, Weifang); Yanli Li (Library of Weifang Medical University, Weifang).

\section{Funding}

This research was supported by two National Natural Science Foundation of China (Project approval No.: 81872719 and 81803337) and the Natural Science Foundation of Shandong Province (Project approval No.: ZR2019MH034).

\section{Availability of data and materials}

All data generated or analyzed during this study are included in this published article and its supplementary information files.

\section{Author's contributions}

$\mathrm{JL}$ conceived and designed the study and wrote the manuscript. YZ adjusted the retrieval strategy and edited the manuscript. JF collected the international data. WM collected the Chinese data. GZ and XW performed data processing. KB and DW reviewed the writing problem. FS and SW work orientation and secured funding for this study. All authors discussed the results and reviewed the manuscript.

\section{Ethics approval and consent to participate}

Ethics approval was not required for this research.

\section{Consent for publication}

Not applicable.

\section{Competing interests}

The authors declare that they have no competing interests.

\section{References}

1. Guo D, Zhu Y, Yin W. OSCAR: a framework to integrate spatial computing ability and data aggregation for emergency management of public health. Geoinformatica. 2018;22(2):383-

2. EM-DAT | The international disasters database.https://www.emdat.be/. Accessed 1 Mar 2019. 
3. Jin H, Lu L, Liu J, Cui M. Complex emergencies of COVID-19: management and experience in Zhuhai, China. Int J Antimicrob Agents. 2020;55(5). doi:10.1016/j.jjantimicag.2020.105961.

4. Makri A. Robert Koch Institute: towards digital epidemiology. The La 2017;390:833.

5. Sun M, Xu N, Li C, Wu D, Zou J, Wang Y, et al. The public health emergency management system in China: trends from 2002 to 2012. BMC Public Health. 2018;18(1):474.

6. Rose DA, Murthy S, Brooks J, Bryant J. The Evolution of Public Health Emergency Management as a Field of Practice. Am J Public Health. 2017;107 Suppl 2:126-

7. Xin Y, Xu K. Hospital emergency management research in China: trends and challenges. Emergency Medicine Journal. 2012;29(5):353-

8. Xiang Y, Na L. How Did Chinese Government Implement Unconventional Measures Against COVID-19 Pneumonia. Risk management and healthcare policy. 2020;13:491-499.

9. Fabian E, Valentin R, Gema A, Augustina J, Günter K, Fabio P, et al. Rapid response in the COVID-19 pandemic: a Delphi study from the European Pediatric Dialysis Working Group. Pediatric nephrology (Berlin, Germany). 2020;35:1669-

10. The speech of Xi Jinping on the 12th meeting of the commission for deepening overall reform of the CPC central committee. Beijing: Ministry of National Defense of the PRC; 2020. http://www.mod.gov.cn/shouye/2020-02/14/content_4860469.htm. Accessed 1 Apr 2019.

11. Sharyn G, Sanya M, Dino P, Len T, Sam B, Krystle M. Hazardous materials emergency incidents: public health considerations and implications. Australian and New Zealand journal of public health. 2020;1; doi:10.1111/1753-6405.12981.

12. Brencic DJ, Meredith P, Adrienne G, H. KM, Luis H, Pasi OG. CDC Support for Global Public Health Emergency Management. Emerg Infect Dis. 2017;23 Suppl:S183-

13. Home-Risk and Resilience Hub. https://www.riskandresiliencehub.com/. Accessed 1 Mar 2019.

14. Vielot N, Horney J. Can Merging the Roles of Public Health Preparedness and Emergency Management Increase the Efficiency and Effectiveness of Emergency Planning and Response? Int J Env Res Pub He. 2014;11(3):2911-21.

15. Jacobson PD, Wasserman J, Botoseneanu A, Silverstein A. The Role of Law in Public Health Preparedness: Opportunities and Challenges. 2012;79(8):297-328.

16. Cohen O, Feder-Bubis P, Bar-Dayan Y, Adini B. Promoting public health legal preparedness for emergencies: review of current trends and their relevance in light of the Ebola crisis. Global Health Action. 2015;8(1):28871.

17. Xu M, Li SX. Analysis of good practice of Public Health Emergency Operations Centers. Asian Pac J Trop Med. 2015;8(8):677-

18. Yao LN, Chen EF, Chen ZP, Gong ZY. From SARS to H7N9: The mechanism of responding to emerging communicable diseases has made great progress in China. Biosci Trends. 2013;7 (6): 290-

19. Zhong S, Clark M, Hou XY, Zang Y. Progress and challenges of disaster health management in China: a scoping review. Global Health Action. 2014;7(1):24986. 
20. Chen, CM. CiteSpace II: Detecting and visualizing emerging trends and transient patterns in scientific literature. Journal of the American Society for Information Science and Technology. 2006;57(3):359-

21. Chen YB, Tong XF, Ren J, Yu CQ, Cui YL. Current Research Trends in Traditional Chinese Medicine Formula: A Bibliometric Review from 2000 to 2016. Evidence-based complementary and alternative medicine. 2019;1-

22. Volet S. Emerging Trends in Recent Research on Motivation in Learning Contexts. 2001; et:319-34.

23. Burmaoglu S, Saritas O, Kidak LB, Berber CJ. Evolution of connected health: a network perspective. 2017;112 (3):1419-1438.

24. Chen SQ, Bie RX, Lai YF, Shi HH. Trends and Development in Enteral Nutrition Application for Ventilator Associated Pneumonia: A Scientometric Research Study (1996-2018). Front in Pharmacol. 2019; doi:10.1007/s801090000086.

25. Knowledge Infrastructure Project in China. http://www.cnki.net/gycnki/gycnki.htm. Accessed 1 Jan 2019.

26. Li J. Chen CM. CiteSpace: text mining and visualization in scientific literature.2nd ed. Shanghai: Capital University of economics and business press; 2016 (Article in Chinese).

27. Wu QH. Public Health Emergency Management. Beijing: People's medical publishing house;2013 (Article in Chinese).

28. Steven F. Crisis management: Planning for the inevitable. New York; 1986.

29. Ping Q, He J, Chen CM. How many ways to use CiteSpace? A study of user interactive events over 14 months. J Assoc Inf Sci Tech. 2017;68(5):1234-

30. Costa DF, Francisval DMC, César DMM, Bruno, Do Prado JW. Bibliometric analysis on the association between behavioral finance and decision making with cognitive biases such as overconfidence, anchoring effect and confirmation bias. Scientometrics. 2017;111(3):1775-99.

31. Meng S, Xiong D. Review and Exploration of China Subtropical Climate Change Research Based on Scientometric Analysis. Trop Conserv Sci. 2018; 11:1-13.

32. Ponce FA, Lozano AM. Highly cited works in neurosurgery. Part I: the 100 top-cited papers in neurosurgical journals. J Neurosurg. 2010;12(2):223-

33. Li J, Jovanovic A, Klimek P, Guo XH. Bibliometric analysis of fracking scientific literature. Scientometrics. 2015;105(2):1273-

34. Li C, Wu K, Wu J. A bibliometric analysis of research on haze during 2000-2016. Environ Sci Pollut R. 2017;24 (32):24733-

35. Zhou W, Kou AQ, Chen J, Ding BQ. A retrospective analysis with bibliometric of energy security in 2000- Energy Rep. 2018;4:724-732.

36. Chen CM. Searching for intellectual turning points: Progressive knowledge domain visualization. Natl. Acad. Sci. USA. 2004; 101 Suppl 1:5303-5310.

37. Zhang J, Zhu F, Sun X, Wang P, Song H. The Evolution of Intellectual Structure in Organization Studies between 1990 and 2010: A Research Based on Bibliometric Analysis. Open Journal of 
Business and Management. 2017;5(3):430-449.

38. Pierpaoli M, Ruello M L. Indoor Air Quality: A Bibliometric Study. Sustainability. $2018 ; 10$ (11):3830.

39. Wang C, Wu J, He X, Ye M, Liu W, Tang R. Emerging Trends and New Developments in Disaster Research after the 2008 Wenchuan Earthquake. Int J Env Res Pub He. 2019;16(29):1-19.

40. Zhu W, Wang Z. The Collaborative Networks and Thematic Trends of Research on Purchasing and Supply Management for Environmental Sustainability: A Bibliometric Review. Sustainability. 2018;10 (5):1510.

41. Small, H. Co-citation in the scientific literature: A new measure of the relationship between two documents. Journal of the American Society for Information Science. 1973;24(4):265-269.

42. Countries | Data. https://data.worldbank.org.cn/country. Accessed 2 Jul 2019.

43. Mona H-A, Jenny L, Casey SR, Allison CS. Elevated Blood Lead Levels in Children Associated With the Flint Drinking Water Crisis: A Spatial Analysis of Risk and Public Health Response. American journal of public health. 2016;106:2.

44. Knowlton, Kim, Rotkin-Ellman, Miriam, King, Galatea, et al. The 2006 California Heat Wave: Impacts on Hospitalizations and Emergency Department Visits. Environmental Health Perspectives. 2009;117(1):61-

45. Wein LM, Liu Y, Bloom BR. Analyzing a Bioterror Attack on the Food Supply: The Case of Botulinum Toxin in Milk. Proceedings of the National Academy of Sciences of the United States of America. 2005;102:28.

46. Embriaco N, Azoulay E, Barrau K, Kentish N, Papazian L. High level of burnout in intensivists: prevalence and associated factors. American Journal of Respiratory \& Critical Care Medicine. 2007;175(7):686.

47. Salim S Abdool Karim, Gavin J Churchyard, Quarraisha Abdool Karim, Stephen D Lawn. HIV infection and tuberculosis in South Africa: an urgent need to escalate the public health response. Lancet. 2009;374(9693):921-33.

48. Karin S, Martina B, Diego A. E, Victoria G, Antonino C, Siro B, et al. Specificity, cross-reactivity, and function of antibodies elicited by Zika virus infection. Ence. 2016;353(6301):823-

49. Daniel P Aldrich, Michelle Meyer. Social Capital and Community Resilience. American Behavioral Scientist. 2014;1-16.

50. Philip J. Peters, Pamela Pontones, Karen W. Hoover, Monita R. Patel, Romeo R. Galang, Jessica Shields, et al. HIV Infection Linked to Injection Use of Oxymorphone in Indiana, 2014-2015. The new england journal of medicine. 2016;375(3):229-

51. Zhongw O, Wang H, Dai J, Baol L, Gan W, Liang J. Emergency Logistics. Journal of Chongqing University. 2004;3(27):164-167 (Article in Chinese).

52. Kaib Z. Review and prospect: construction of emergency management system in China. Political science research. 2009;1:80-90 (Article in Chinese). 
53. Jih M. Legislative situation and characteristics of China's emergency law. Law forum. 2003;4:6-13 (Article in Chinese).

54. Yuc M. Legal construction of public emergency response in China: legal construction task proposed by SARS crisis management practice. Journal of Renmin University of China. 2003;4:97-102 (Article in Chinese).

55. Yuc M. The realistic subject of administrative rule of law in public emergency management. Jurist. 2003;4:119-129 (Article in Chinese).

56. Richard L Siegel. Code 9: A systematic approach for responding to medical emergencies occurring in and around a hospital. Ann Emergency Med. 1991;20(1):77-

57. Qiul J, Shuq S, Guoz Y, Jingj S, Shuai S, Yuanh H. Analysis of knowledge bases and research hotspots of coronavirus from the perspective of mapping knowledge domain. Medicine 2020; 99(22). doi:10.1097/MD.0000000000020378.

58. Tiew J. Capacity-building for public health emergency response to disasters. Disease surveillance. 2003;18 (4):143-147 (Article in Chinese).

59. Du HS, Ke X, Chu SKW, Chan LT. A bibliometric analysis of emergency management using information systems (2000-2016). Online Inform Rev. 2017;41(4):454-470.

60. Xie Q, Xiao Z, Liang X, Yang Q. Emergency capability construction of institution of disease prevention and control. J Prev. Med Inf. 2005; 21:60-61.

61. CDC Fact Sheet. https://www.cdc.gov/globalhealth/strategy/pdf/2012-gh-strategy-and-annualreport-summar pdf. Accessed 2 Jul 2019.

62. Memish ZA. Public Health Emergency Operations Center - A critical component of mass gatherings management infrastructure. The Journal of Infection in Developing Countries. 2016;10(8):785-90.

63. Noji EK. The nature of disaster: general characteristics and public health effects. The Public Health Consequences of Disasters.1997;3-20.

64. Fan $L$, Zhao Q. The status quo of emergency management system for sudden public health events in America and Japan and its enlightenment. Chinese Nursing research. 2011;7:9-11 (Article in Chinese).

\section{Figures}




\section{Data Sources}

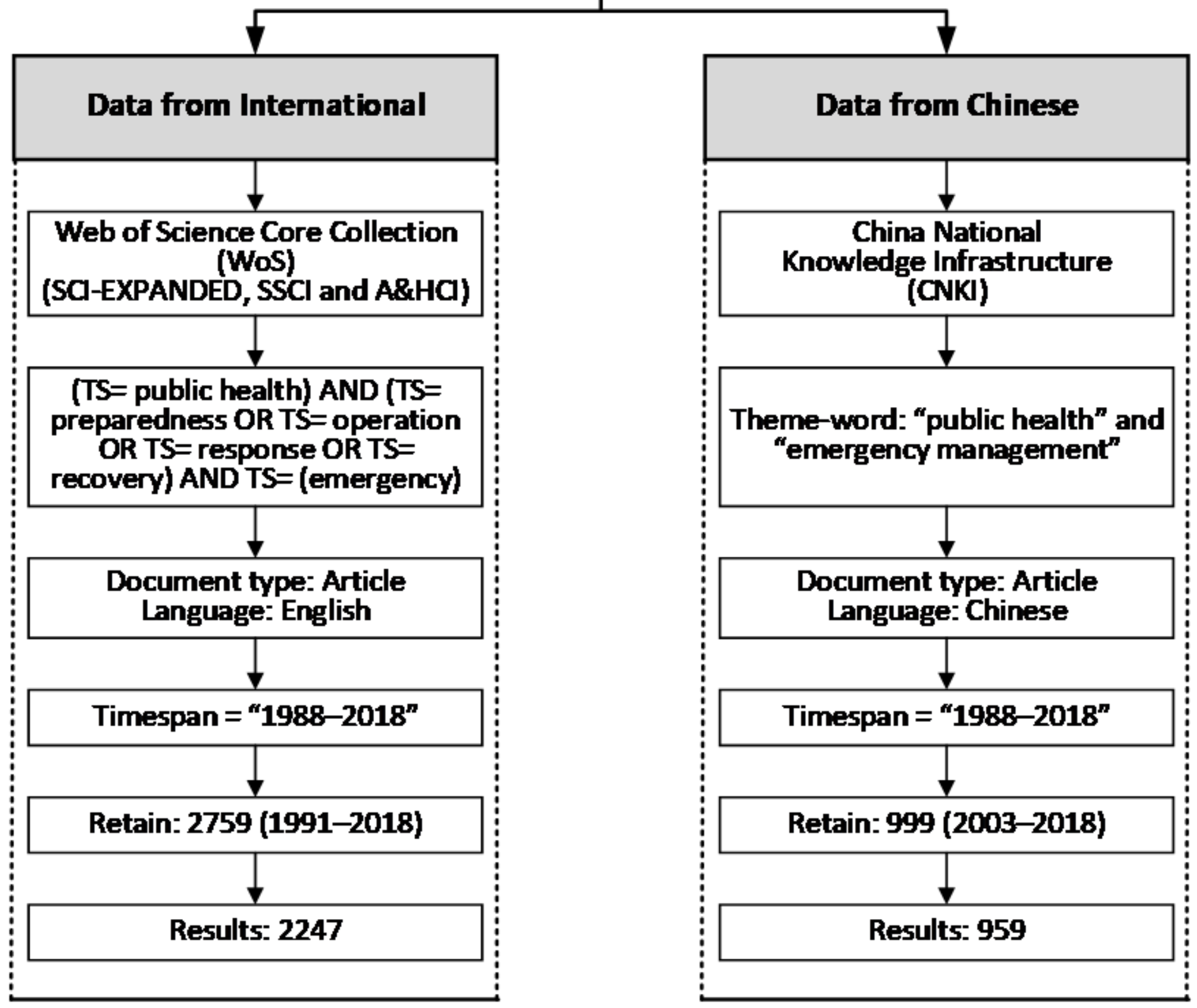

Figure 1

Retrieval procedure of study data 


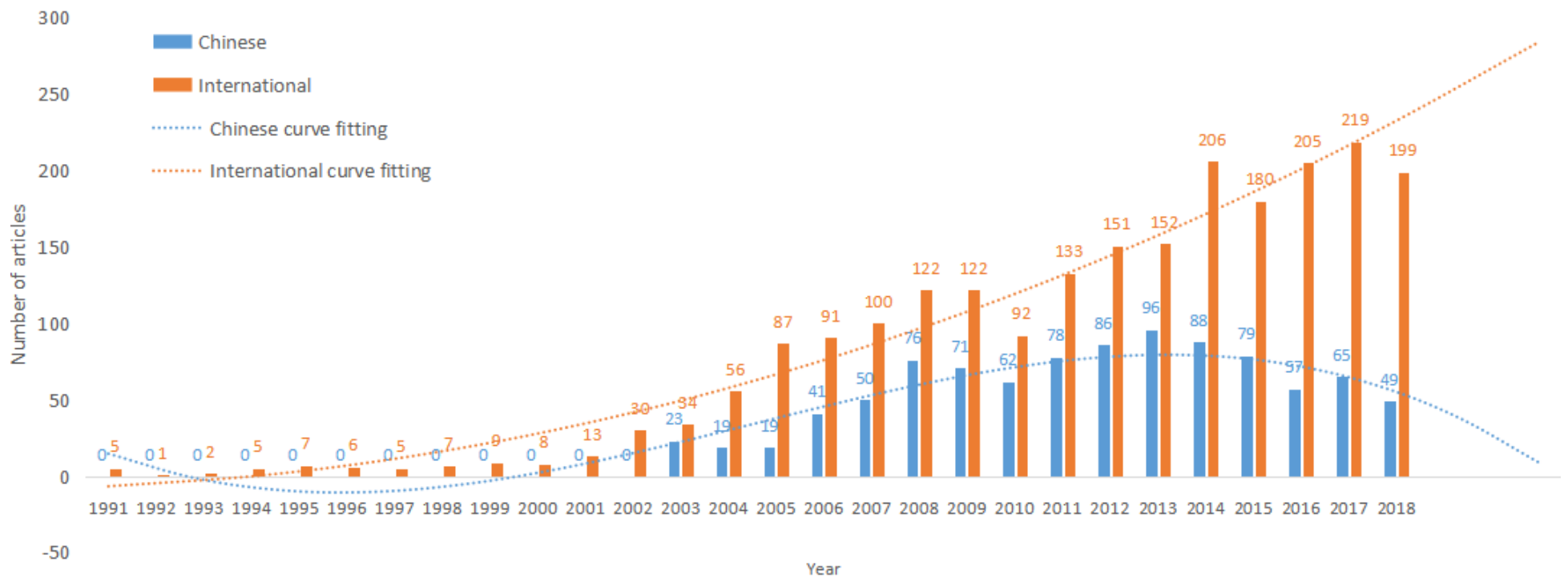

\section{Figure 2}

Temporal distribution and trend of international and Chinese PHEM study

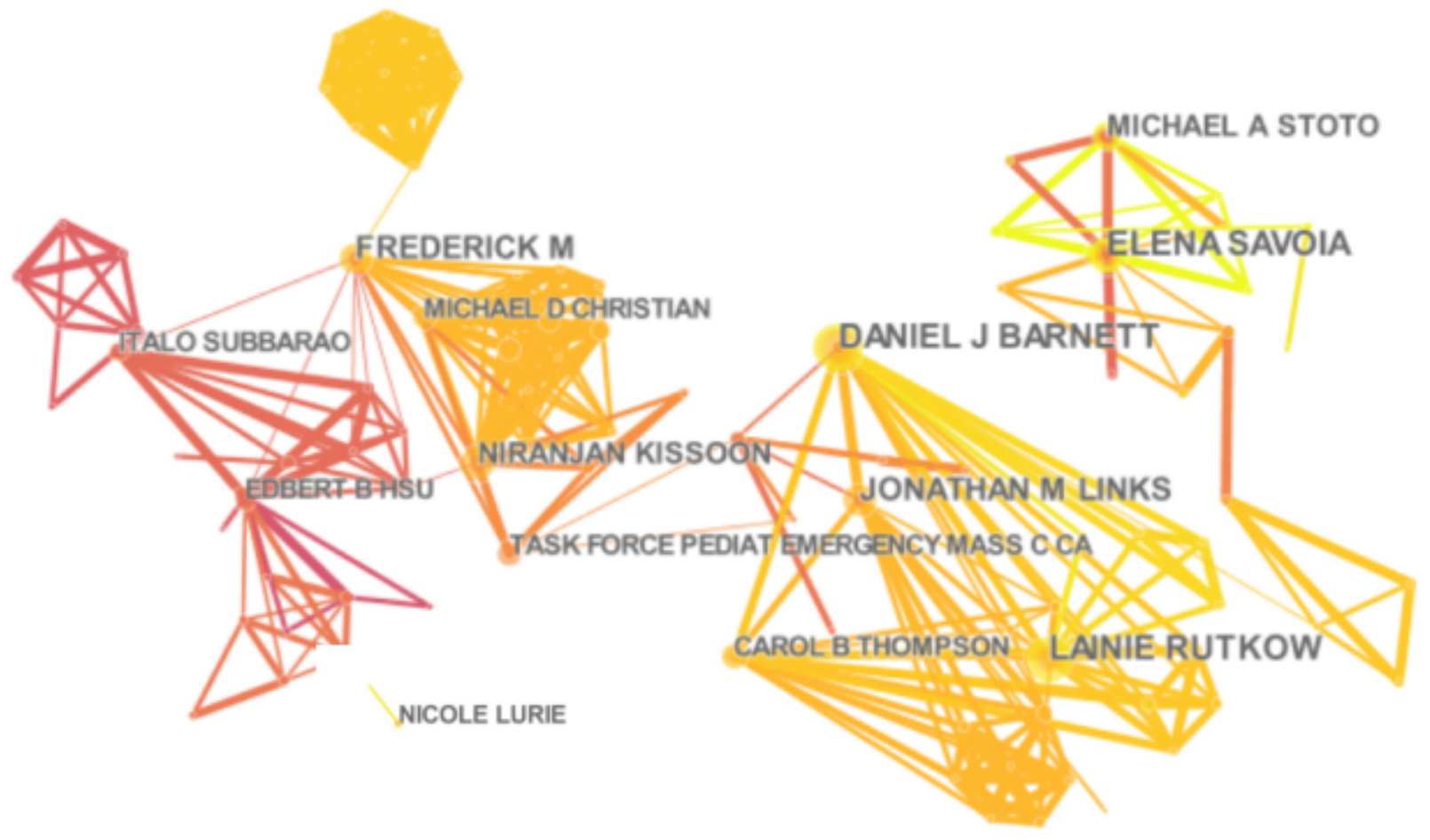

Figure 3

Co-author network of international database 


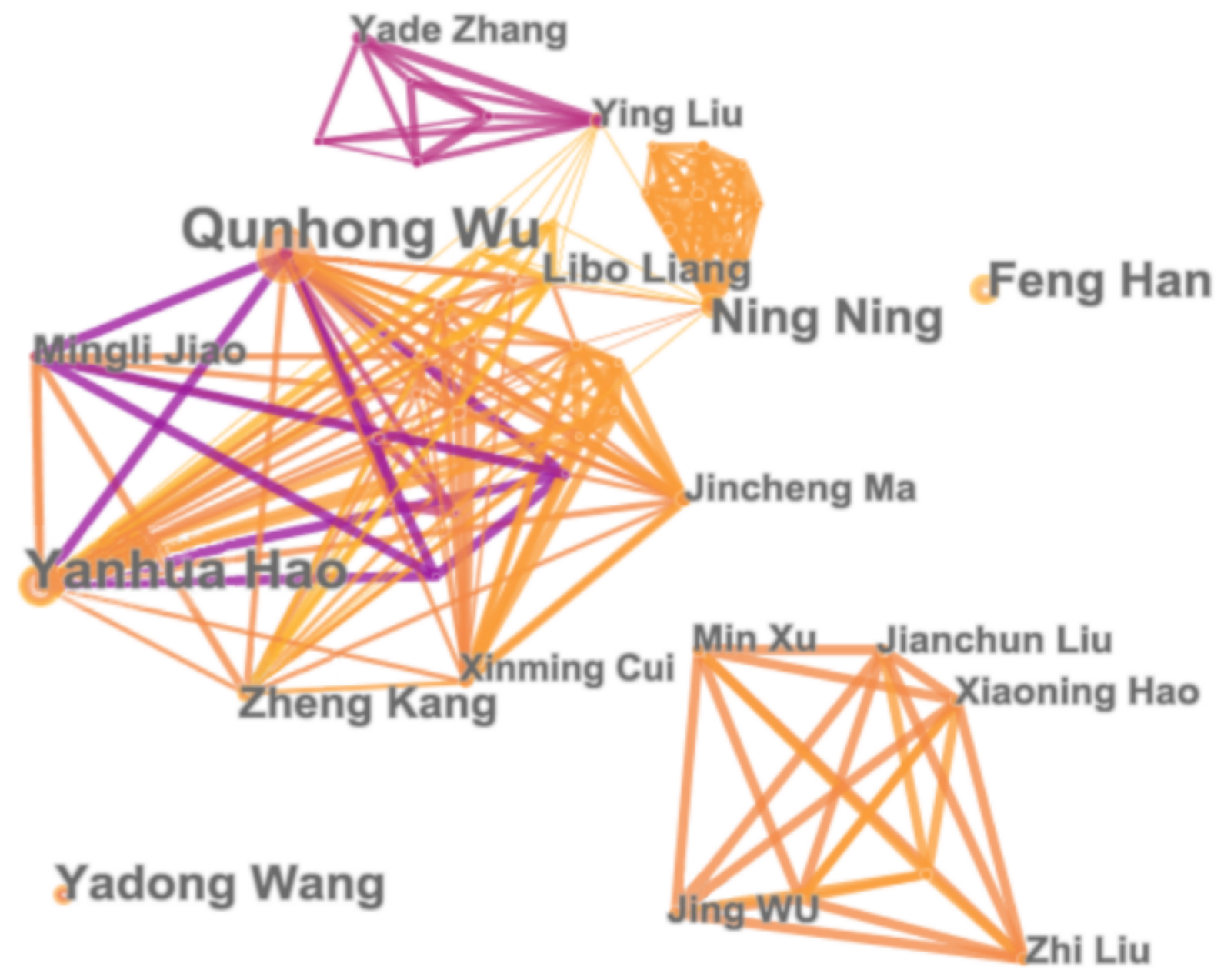

Figure 4

Co-author network of Chinese database 




\section{Figure 5}

Co-institution network of international database

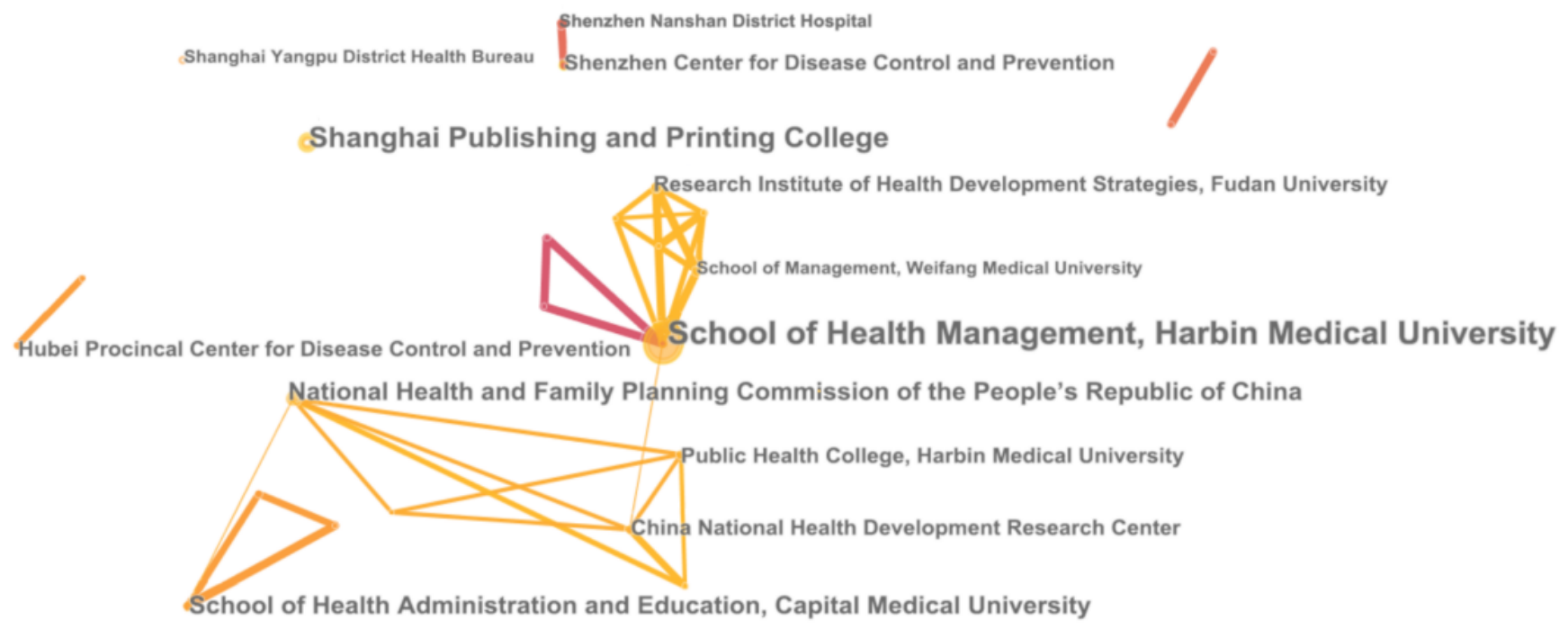


Figure 6

Co-institution network of Chinese database

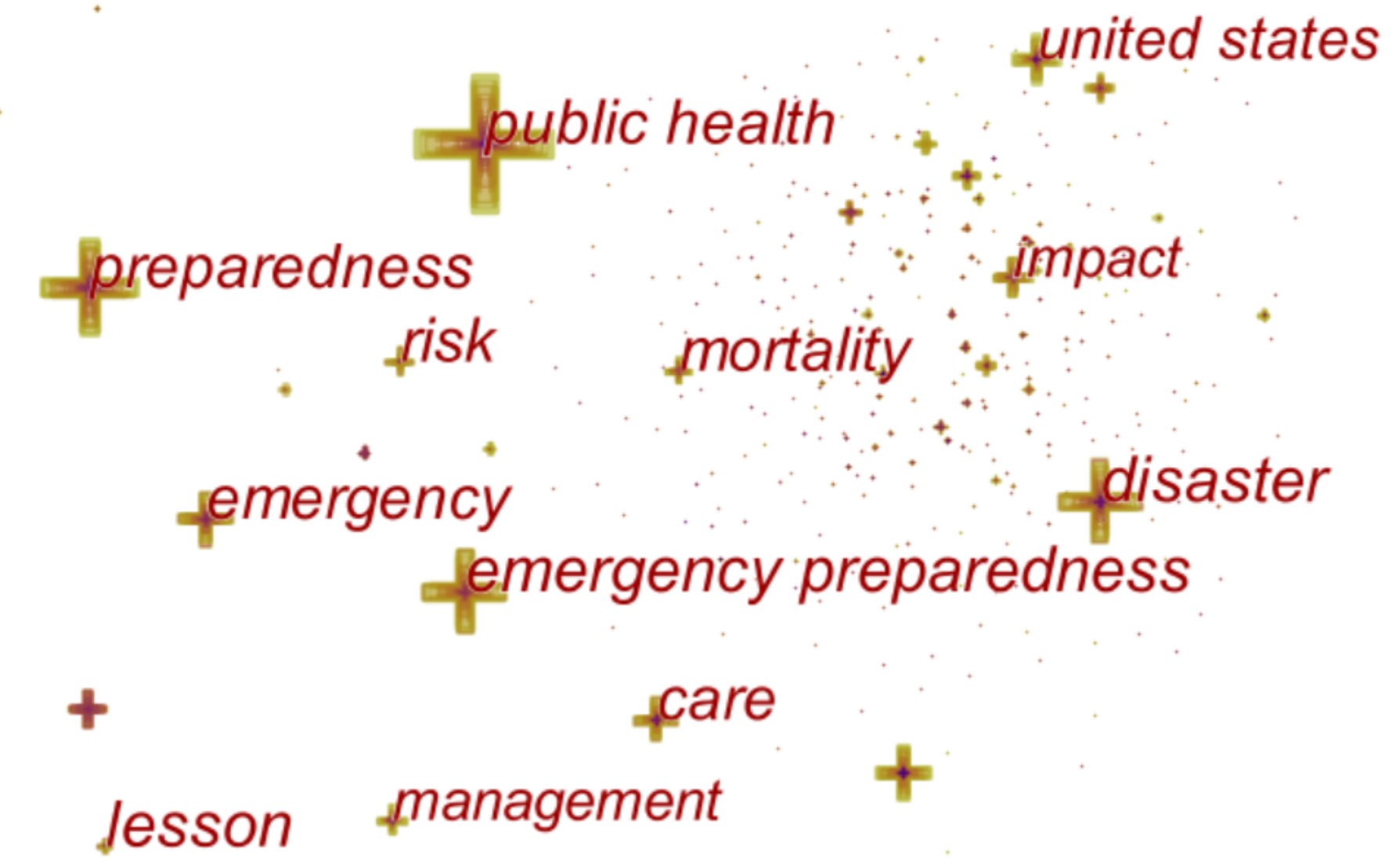

Figure 7

Keywords co-occurrence network of international database 


\section{emergency management}

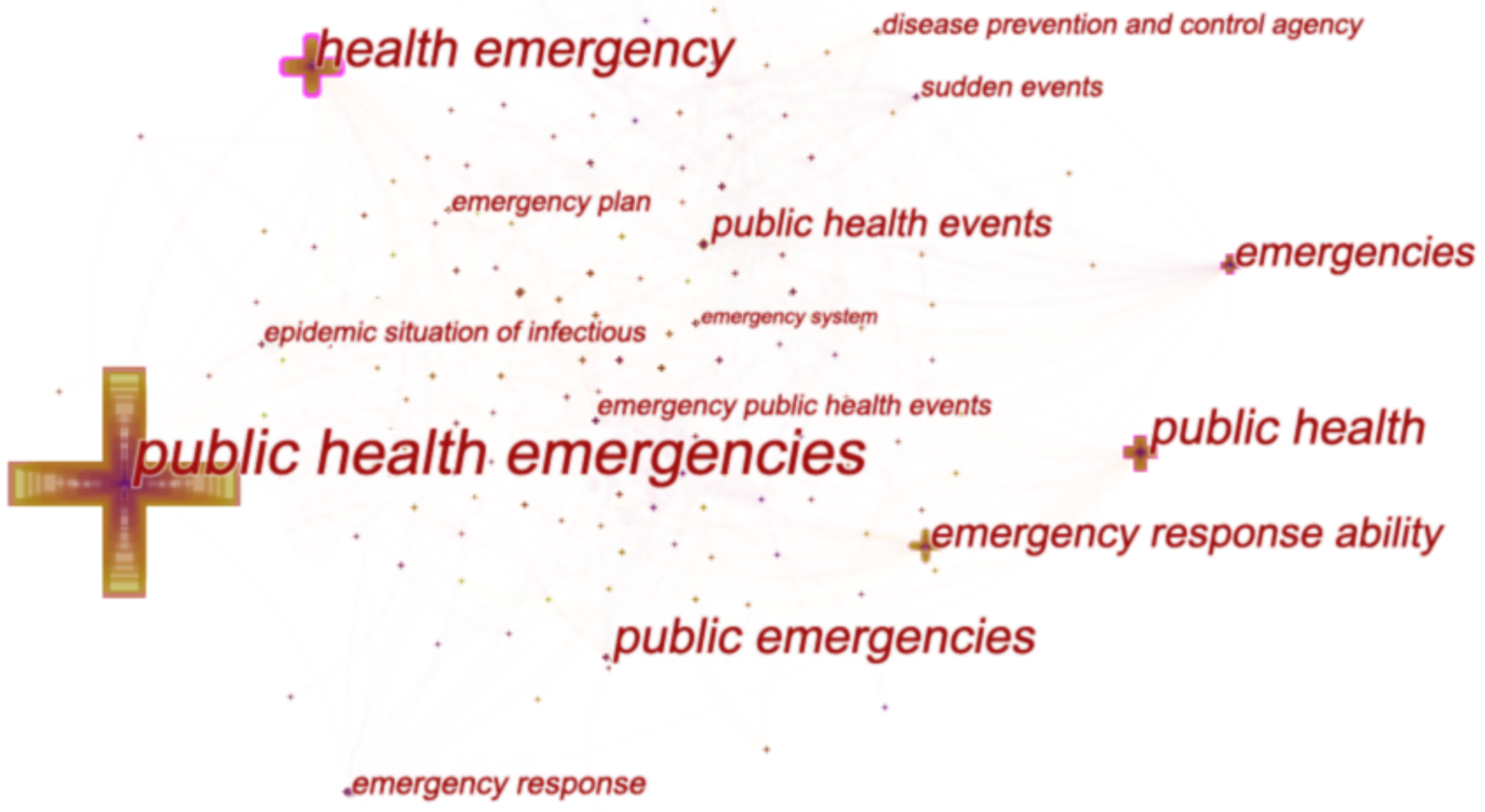

Figure 8

Keywords co-occurrence network of Chinese database 


\section{Top 52 Keywords with the Strongest Citation Bursts}

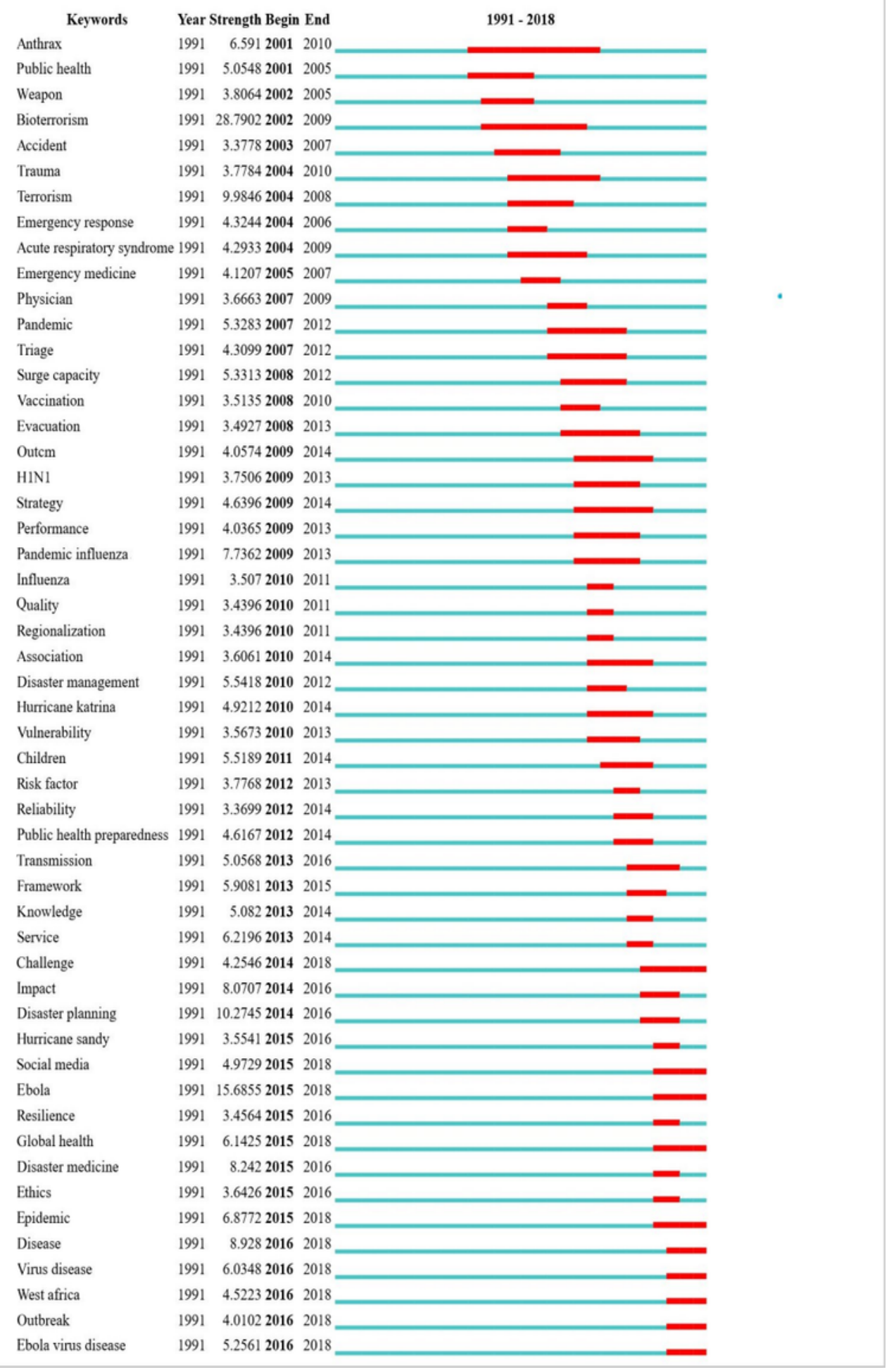

\section{Figure 9}

Keywords with the strongest citation bursts of international database 


\section{Top 18 Keywords with the Strongest Citation Bursts}

\begin{tabular}{lllll}
\multicolumn{1}{c}{ Keywords } & \multicolumn{3}{c}{ Year Strength Begin End } \\
Public health emergencies & 2003 & $3.1858 \mathbf{2 0 0 3}$ & 2008 \\
United States of America & 2003 & 3.0961 & $\mathbf{2 0 0 3}$ & 2007 \\
North America & 2003 & 3.0961 & $\mathbf{2 0 0 3}$ & 2007 \\
Emergency disposal & 2003 & $4.4548 \mathbf{2 0 0 3}$ & 2007 \\
United States & 2003 & $2.8848 \mathbf{2 0 0 3}$ & 2007 \\
Sudden events & 2003 & $3.031 \mathbf{2 0 0 3}$ & 2008 \\
Public health & 2003 & $4.9423 \mathbf{2 0 0 4}$ & 2006 \\
Emergency & 2003 & $4.5763 \mathbf{2 0 0 6}$ & 2010 \\
Emergency response & 2003 & $3.6704 \mathbf{2 0 0 6}$ & 2007 \\
Public emergencies & 2003 & $3.1473 \mathbf{2 0 0 6}$ & 2009 \\
Disease prevention and crotrol agency & 2003 & $4.197 \mathbf{2 0 0 9}$ & 2011 \\
Evalute & 2003 & $4.6988 \mathbf{2 0 1 0}$ & 2011 \\
Emergency drill & 2003 & $3.3187 \mathbf{2 0 1 1}$ & 2013 \\
Risk assessment & 2003 & $3.1053 \mathbf{2 0 1 3}$ & 2016 \\
Assessment & 2003 & $2.8618 \mathbf{2 0 1 4}$ & 2016 \\
Health Emergency management & 2003 & $2.8861 \mathbf{2 0 1 6}$ & 2018 \\
Health Emergency response ability & 2003 & $2.8861 \mathbf{2 0 1 6}$ & 2018 \\
Delphi method & 2003 & $3.2337 \mathbf{2 0 1 6}$ & 2018 \\
\hline
\end{tabular}

Figure 10

Keywords with the strongest citation bursts of Chinese database

\section{Supplementary Files}

This is a list of supplementary files associated with this preprint. Click to download.

- Supplementarymaterialrevisedversion.doc 